\title{
Coastal wetlands of India: threats and solutions
}

\author{
Salom Gnana Thanga Vincent $\mathbb{D} \cdot$ Katharine A. Owens
}

Received: 3 August 2021/Accepted: 5 August 2021/Published online: 10 August 2021

(C) The Author(s), under exclusive licence to Springer Nature B.V. 2021

\section{Introduction}

Wetlands provide valuable functions benefitting humans and wildlife. These include recharging groundwater, providing food, storing, filtering and purifying surface waters, offering biodiversity habitat, maintaining the global water cycle, regulating natural hazards, supporting livelihoods, protecting from floods, reducing risk, sequestering carbon, mitigating climate change effects, and they can also be of cultural and spiritual importance (Prasad et al. 2002; Ramsar Convention on Wetlands 2018; Schuyt and Brander 2004). Coastal wetlands stabilize shorelines, buffer from storms and storm surges, and they provide spawning and nursery functions for myriad species, contributing greatly to healthy ecosystems and the economy (Schuyt and Brander 2004). With a long coastline of $7516 \mathrm{~km}$ and a peninsular structure along eight states in the south, the coastal wetlands of India include those in the east coast, the west coast of mainland India, and the Andaman and Nicobar islands. The coast of India harbours coral reefs, rocky coasts and coastal wetlands including mangroves,

S. G. T. Vincent ( $\square)$

University of Kerala, Thiruvananthapuram,

Kerala 695581, India

e-mail: salom@keralauniversity.ac.in

K. A. Owens

University of Hartford, West Hartford,

CT, USA estuaries, lagoons, creeks, tidal/mud flats, salt marshes numbering 3497 coastal wetlands and comprising a total area of 3,880,569 hectares (Garg and Patel 2007). Natural coastal wetlands comprise $24.27 \%$ of India's total wetlands (Bassia et al. 2015). Mangroves are the predominant type of coastal wetlands in India occupying an area of 4,87,100 hectares. Mangroves of India may be either tide dominated (e.g., the Sunderbans, in the east of India) or river dominated (e.g., the Pitchavaram in Tamil Nadu). Drowned valley type mangroves are found in Gujarat (Sulochanan et al. 2016), which were inundated during the 20th Century due to sea level rise and stand as a testimony to global warming impacts. Forty percent of the Sunderbans, the largest mangrove wetland in the world, can be found in India. In addition, salt pans and aquaculture ponds are categorized as human-made coastal wetlands.

On a larger scale, the east and west coasts vary in geomorphic settings. Wetlands of the west coast evolved during the Late Quaternary and occur as an interlacing network (Padmalal et al. 2011) featuring a narrow stretch with steep slope. Most of the rivers that originate from the Western Ghats and drain into the Arabian sea in the west coast are small or medium sized (catchment area ranging approximately from 100 to $5000 \mathrm{~km}^{2}$ ). This results in small-sized coastal wetlands in the west coast. In contrast, the coastal wetlands of the east coast are larger, harbouring higher diversity (Sulochanan et al. 2016), they often extend over the delta of large rivers. In India, $56.7 \%$ of the 
mangrove swamps area is in the east coast and 23.5\% in west coast, with the remaining found in the Andaman and Nicobar Islands (Fig. 1). The coastal wetlands of the southeastern coast are heavily influenced by urbanization and industrial development, and their area decreased by $8 \%$ from 1988 to 2016 (Jacintha et al. 2019).

The coastal wetlands of India are endowed with rich biodiversity of coastal fauna and flora like seagrasses, corals, fish, birds molluscs, crustaceans, diatoms, reptiles and mammals. Coastal wetlands also support the existence of endemic, charismatic and flagship species like the Royal Bengal tiger, Olive Ridley turtle, Irrawadday dolphin, and the Pearl spot, to name but a few. The burgeoning economic activity in coastal ecosystems or "blue economy" supported by several industries like fishing, tourism, transport, and pharmaceuticals of coastal wetlands significantly contribute to the GDP of the country and provide livelihood to millions as well. In India, mangroves are widely reported to play a major role in carbon sequestration, thus acting as a carbon sink.

Nevertheless, the long coastline of India is inhabited by a dense population of nearly 250 million living within $50 \mathrm{~km}$ of the sea. This combination of economic activity and increasing population exerts pressure on the coastal ecosystem that is already affected by pressures due to climate change. Upstream changes in hydrology and sediment fluxes coupled with changes in salinity patterns negatively impacts coastal wetlands like mangroves and estuaries. Examples are the emerging dead zones in the Bay of Bengal and the oxygen minimum zones in the Arabian sea (Hossain 2020; McCreary et al. 2013). The question of whether coastal wetlands act as net sources or sinks of organic carbon is debated widely by scientists around the world. This depends on the hydrology and the biogeochemistry of coastal wetlands. Emission of greenhouse gases such as methane and nitrous oxide have showed considerable increase in polluted compared to unpolluted coastal wetlands (Purvaja and
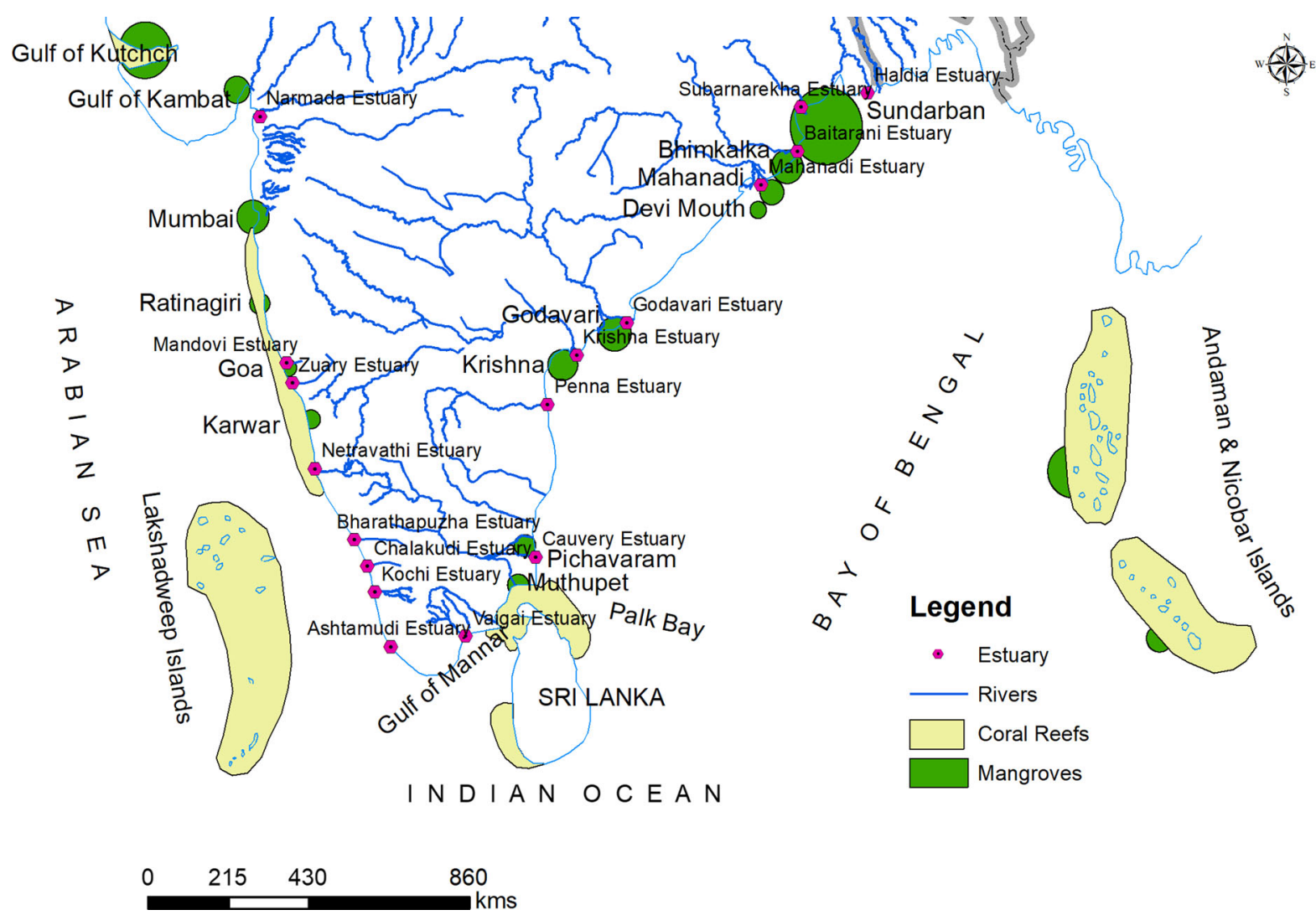

Fig. 1 Coastal wetlands of Southern India 
Ramesh 2001; Reshmi et al. 2015; Salahudeen et al. 2018; Vincent et al. 2017). Increasing urbanisation coupled with poor waste management practices lead to disposal of vast quantities of urban litter in coastal wetlands, thus causing destruction of the natural ecohydrology of these systems (Sulochanan et al. 2016). Tourism is a major industry based on thriving coastal wetlands of India, and this sector of the economy is negatively impacted by improper waste management and littering of urban wastes.

The first focus meeting of Estuarine and Coastal Sciences Association (ECSA) was held at the University of Kerala, Thiruvananthapuram as a three day national seminar on Environmental Status of Estuarine and Coastal Ecosystems in India, ECEI-2019 (14th15th March 2019). The seminar included five keynote talks, 36 oral presentations and 23 poster presentations. Following the seminar, papers were invited for this special issue of Wetland Ecology and Management in the theme of the seminar, "Coastal Wetlands of India: Threats and Solutions".

This special issue of coastal wetlands of India has eleven papers sharing key research that defines the status of coastal wetlands of India. A review on the adaptive potential of the coastal wetlands of India (Ragavan et al. 2020) critically discusses the measures for sustainable management. This issue also includes three papers on coral reefs, including a discussion of the health status and conservation of Lakshadweep coral islands (Gopi et al. 2021), an investigation of the microplastics impregnated in coral annual growth (Krishnakumar et al. 2021) and a report on the bleaching effects of shallow water coral reefs of the Andaman islands (Malakar et al. 2020). Three papers focus on India's mangroves, including a report on the microphytobenthic assemblages in the mangroves of India's west coast (Jeslin et al. 2021), a study on the heavy metal pollution in the west coast mangrove ecosystem (Sarath and Puthur 2020), and a palaeoecological reconstruction highlighting the distribution of palynomorph in the east coast's second largest mangrove (Srivastava et al. 2021). The issue also includes an investigation of the community structure of chaetognath, a major zooplankton taxon in the South Eastern Arabian Sea (Purushothaman et al. 2021). In addition, this issue includes research focusing on the diversity and distribution of molluscs in the Ashtamudi estuary, a Ramsar site in the west coast of India (Ravinesh et al. 2021), a report on the diversity of freshwater sponges in India's coastal waters (Saxena 2021), and an examination of the erosion of beaches in the west coast of India (Sajinkumar et al. 2020) using remote sensing techniques.

\section{Summary of findings}

Ragavan et al. (2020) analyze the status of and critically review the adaptive potential of the coastal wetlands of India. Among the various coastal wetlands, mangroves and coral reefs are widely studied and most of the studies pertain to ecology and biodiversity at large, whereas management aspects are often ignored. There can also be methodological inconsistencies when reporting the area of coastal wetlands, which requires improvement in understanding the definition, characteristics and inventory of these important ecosystems. Several laws and policies have been framed with regard to wetland conservation in India, in addition to the fact that India is a signatory to the Ramsar Convention and the Convention on Biological Diversity (CBD). However, effective enforcement of these regulations is lacking, thus making the coastal wetlands vulnerable to increasing stressors including land use change, rapid and uncontrolled development activities, and climate change. Existing conservation measures were mostly confined to declaration of marine and coastal protected areas (MCPA). Nevertheless, poor infrastructure and lack of resources acted as inhibiting factors in achieving the primary goals of MCPAs. The declaration of protected areas may prevent certain stressors like timber extraction, while other drivers of degradation cannot be controlled through this designation. The National Environmental Policy of 2006 directed the notification of Wetlands (Conservation and Management) Rules, 2010, which was later replaced by the Ministry of Environment, Forest and Climate Change (MoEF\&CC) in 2017. The Coastal Regulation Zone (CRZ) of 2018 had a significant role in protecting the coastal wetlands by classifying them as ecologically sensitive areas. Vertical adjustment and horizontal movement are considered to be innate potentials of coastal wetlands to adapt and cope up with environmental and anthropogenic changes. Safeguarding this adaptive potential and strengthening governance for site-specific management is the need of the hour for effective conservation of coastal wetlands in India. 
Gopi et al. (2021) investigate the health status and conservation of coral reefs across ten inhabited islands of Lakshadweep. The authors create a 'composite condition' index based on several characteristics of coral reef ecosystems like live coral cover, species richness and diversity, mortality index, etc. The live coral cover of the islands ranged from $64.5 \%$ (Kadmat Reef) to $8.50 \%$ (Andrott Islands). In addition to anthropogenic pressures, natural events like the El Nino Southern Oscillation (ENSO) have resulted in destruction of coral reefs in these islands, compounded by major mass coral bleaching events in 1998 and 2010. Coral mortality has also been impacted by the naturally occurring process of sponge invasion. In their paper, Gopi et al. (2021) describe assigning three coral conservation classes to the reef ecosystems of Lakshadweep, determining good overall coral reef condition. The authors also provide details on sustainable use of coral reef resources and suggest conservation practices.

Malakar et al. (2020) explore the extent of coral bleaching and competition among benthic substrates of shallow water coral reefs of the Andaman and Nicobar islands. The authors observed summer bleaching of corals before the onset of monsoon and suggest that the repeated bleaching of corals have changed the benthic dynamics of the coral reef ecosystems in the Andaman and Nicobar islands. They detected a shift in the dominance of coral reef to macroalgae and sponge. Namely, repeated coral bleaching events have led to a benthic substrate change towards multispecies domination of macroalgae and single species domination of sponges. The factors influencing such phase shifts (i.e., temperature increase due to climate change) should be taken into consideration while suggesting management plans for the protection of coral reef ecosystems. Krishnakumar et al. (2021) found microplastics impregnated coral in the annual growth band of Porites sp. in the southeast coast of India's Gulf of Mannar. The results show that nylon was the predominant type followed by polyester. The authors indicate the sources of microplastics are tourism and occurrence of microplastics, controlled by oceanic currents and sediment resuspension (Krishnakumar et al. 2021).

Jeslin et al. (2021) identified 110 species of microphytobenthos (MPB) classified under 49 genera in the mangrove ecosystems along the southwest coast of India. In shallow neritic waters such as mangroves, microphytobenthos, also referred as "secret gardens", contribute greatly to primary productivity. The samples were dominated by diatoms. The authors observed spatial variations in the type of microphytobenthic community structure along the coast. Environmental factors including temperature, nutrient levels, and dissolved oxygen influence the MPB community composition. (Srivastava et al. 2021) used palynomorph distribution patterns along the salinity gradient of mangrove to study palaeoecological reconstruction. They hypothesized that the relationship between palynomorphs and environmental parameters can indicate climate change, sea level, flooding and anthropogenic disturbance. Their study identified five mangrove species and 63 palynomorphs in Conringa mangroves. The authors calculated palynomarine index (PMI) based on the ratio between marine and terrestrial palynomorphs, showing restricted tidal inundation in the southern part of the wetland (Srivastava et al. 2021). This change in inundation was attributed to the conversion of mangrove forests to salt pans and paddy fields. Sarath and Puthur (2020) assessed the heavy metal pollution in the mangrove soils of Kadalundi Vallikunnu Community Reserve (KVCR) on the southwest coast of India. Using bioconcentration factor (BCF) and heavy metal pollution index (HPI) they determined the extent of heavy metal pollution, detecting heavy metals such as $\mathrm{Mn}, \mathrm{Fe}, \mathrm{Ni}, \mathrm{Cu}, \mathrm{Pb}$ and $\mathrm{Zn}$ in the sediment samples. They found, however that the HPI of KVCR is low due to the diverse flora which accumulates the heavy metals. The BCF values highlight the suitability of mangroves in the remediation of heavy metals from contaminated soils.

To study the influence of upwelling on the chaetognath communities, Purushothaman et al. (2021) investigated the community structure and distribution of chaetognaths along the upwelled and non-upwelled waters of the Southeastern Arabian Sea (SEAS). Chaetognath, commonly referred as "arrow worms", are a major zooplankton taxon and they are also highly versatile in their distribution. The authors observed spatial variation in abundance and diversity of chaetognaths with high abundance in the upwelled southern part compared to the non-upwelled northern part. In addition, they found diversity of chaetognaths was higher in non-upwelled waters. Environmental factors such as temperature, dissolved oxygen and copepod abundance were found to influence the 
distribution pattern of chaetognath communities in SEAS.

Ravinesh et al. (2021) studied the diversity and distribution of molluscan fauna within the Ashtamudi estuary, a Ramsar site in Kerala, India. Molluscan fauna, being soft bodied organisms, are more prone to anthropogenic pressures such as pollution and molluscs serve as indicators of ecosystem disturbances. The molluscan diversity was comparatively high in Ashtamudi when considering other estuaries in India. In Ashtamudi estuary, Gastropoda was the predominant species in diversity followed by Bivalvia and Polyplacophora. Moreover, the molluscan species assemblage was higher in the mangrove dominated region of Ashtamudi than in the open lake. Loss of mangrove cover in Ashtamudi due to unsustainable development activities is a threat to molluscan abundance and diversity due to habitat loss.

Along the coastline of India, freshwater wetlands occur in addition to marine ecosystems. Saxena's (2021) detailed the occurrence of fresh water sponge fauna in India's coastal waters. Despite their importance in providing ecosystem services, the taxonomy and ecology of lower invertebrates such as sponge fauna are less explored. Among the 30 species of freshwater sponges in India, 29 species were found to inhabit the coastal wetlands and 10 are endemic. Sponges being good candidates for cytological and regenerative studies, their diversity in the Indian coasts needs to be explored further. Beach erosion in the southern west coast of India was studied by Sajinkumar et al. (2020) using Persistent Scatterer Interferometric Synthetic Aperture Radar (PSInSAR), a remote sensing technique. Ground deformation measurements from PSInSAR processing indicated that the study area was characterized by phases of erosion and deposition. These findings were supported by results from sediment texture and grain microtexture analysis. The erosion, deposition, and beach build-up in the monsoon-dominated beaches corresponded to the onset of southwest monsoon in the Arabian sea. Depositional zones occured near to river or lake inlets while erosional zones were found away from them. The study emphasized the usefulness of using PSInSAR technique along with google earth images and beach sediment characteristics in examining the morpho-dynamics of coastal beach environment.

\section{Conclusion and future prospects}

Coastal wetlands of tropical countries face impounding anthropogenic pressures from a high population and burgeoning economic activities, and this leads to the rapid loss of these ecosystems. The majority of such pressures are related to conversion of the coastal wetlands for agriculture, intensive aquaculture, tourism and transport, disposal of industrial wastes and untreated sewage, encroachment for construction. Such changes impact the hydrology, physico-chemical and biological processes of the coastal ecosystems (Bassi et al. 2014; Prasad et al. 2002). This anthropgenic pressure will be exacerbated by a changing climate, an increase in extreme temperatures, and rising seas. The coastal wetlands of mainland India and Andaman and Nicobar islands are endowed with rich biodiversity owing to their functions as nursery grounds and protective barrier against cyclones. Yet, while these wetlands are critically important ecosystems with diverse flora and fauna and key economic benefits, their ecological functioning, niche patterns, and biodiversity are not well-studied.

Indian wetlands undergo a wide range of stressors including land use change, rapid and uncontrolled development activities, skyrocketing population levels, and climate change. As the papers in this Special Issue show, India's coastal wetlands are showing clear evidence of on-going degradation from microplastic uptake to heavy metal pollution, to the growing impact of erosion on India's west coast and encroachment by urbanization and agriculture. The economic and environmental services of coastal wetlands are at stake due to these multiple pressures, yielding calls for urgent measures for conservation. While Marine and Coastal Protected Areas and the Ramsar Convention are important to protecting and preserving wetland habitats, these efforts are complemented by better enforcing regulations that already apply to Indian wetland systems. Presently, there are several robust policies for conservation of coastal ecosystems in India. The government of India has established ecological sensitive areas (ESA) along the mainland coasts as well as in the islands of the east and west coasts under the The Coastal Regulation Zone (2011) notification. In addition, the Integrated Island Management Plan (IIMP) was implemented to conserve the coral reef ecosystem of the Lakshadweep islands. Policies such as the Convention of 
Biodiversity, the National Environmental Policy (2006), the notification of Wetlands (Conservation and Management) Rules (2010), and Ministry of Environment, Forest and Climate Change (2017) provide a framework to bolster these key habitats. However, through proper site-specific management practices, there is a large potential to enhance the carbon sequestration capacity of the coastal wetlands, to enhance their potential in climate change mitigation, and to better undrestand their role in potential international carbon trading systems. That said, conservation measures and tangible initiatives must be spearheaded towards regional scale for protection of coastal wetlands in India.

Funding This MS is a synthesis paper of the special issue of WEM. There is no funding source for this MS.

\section{References}

Bassi N, Kumar MD, Sharma A, Pardha-Saradhi P (2014) Status of wetlands in India: a review of extent, ecosystem benefits, threats and management strategies. J Hydrol 2:1-19

Bassia N, Kumar MD, Sharma A (2015) Indian wetlands under threat! India Water Portal. indiawaterportal.org/articles/ Indian-wetlands-under-threat. Accessed 27 July 2021

Garg JK, Patel JG (2007) National wetland inventory and assessment-technical guidelines and procedure manual. Retrieved from Space Applications Centre, Indian Space Research Organisation (ISRO), Ahmedabad, India:

Gopi M, Jeevamani JJJ, Goutham S, Simon NT, Samuel VD, Abhilash KR, Robin RS, Hariharan G, Muruganandam, R, Krishnan P, Purvaja, R (2021) Status of health and conservation classification of tropical coral reefs in Lakshadweep archipelago. Wetlands Ecology and Management $: 1-16$.

Hossain M (2020) Persistent Pollution in the Bay of Bengal: An Emerging Issue for Regional Ocean Governance. Persistent Pollution in the Bay of Bengal: An Emerging Issue for Regional Ocean Governance (May 8, 2020).

Jacintha T, Rajasree SR, Kumar JD, Sriganesh J (2019) Assessment of wetland change dynamics of Chennai coast, Tamil Nadu, India, using satellite remote sensing. Indian J Geo Mar Sci 48(08):1258-1266

Jeslin IJ, Benny N, Thomas LC, Padmakumar KB (2021) Short term spatio-temporal variabilities of microphytobenthic assemblages in the mangrove ecosystems along the southwest coast of India. Wetl Ecol Manag. https://doi.org/ 10.1007/s11273-021-09787-8

Krishnakumar S, Anbalagan S, Hussain SM, Bharani R, Godson PS, Srinivasalu S (2021) Coral annual growth band impregnated microplastics (Porites sp.): a first investigation report. Wetl Ecol Manag. https://doi.org/10.1007/ s11273-021-09786-9
Malakar B, Venu S, Samuel VD, Abhilash KR (2020) Increasing signs of degradation of shallow water coral reefs due to repeated bleaching and spatial competition among benthic substrates. Wetl Ecol Manag. https://doi.org/10.1007/ s11273-020-09744-X

McCreary JP Jr, Yu Z, Hood RR, Vinaychandran PN, Furue R, Ishida A, Richards KJ (2013) Dynamics of the Indianocean oxygen minimum zones. Prog Oceanogr 112:15-37

Padmalal D, Kumaran KPN, Nair KM, Baijulal B, Limaye RB, Mohan SV (2011) Evolution of the coastal wetland systems of SW India during the holocene: evidence from marine and terrestrial archives of Kollam coast, Kerala. Quatern Int 237:123-139

Prasad SN, Ramachandra TV, Ahalya N, Sengupta T, Kumar A, Tiwari AK, Vijayan VS, Vijayan L (2002) Conservation of wetlands of India-a review. Trop Ecol 43(1):173-186

Purushothaman A, Thomas LC, Nandan SB, Padmakumar KB (2021) Influence of upwelling on the chaetognath community along the Southeastern Arabian Sea. Wetl Ecol Manag. https://doi.org/10.1007/s11273-020-09773-6

Purvaja R, Ramesh R (2001) Natural and anthropogenic methane emission from coastal wetlands of South India. Environ Manag 27(4):547-557. https://doi.org/10.1007/ s002670010169

Ragavan P, Kathiresan K, Mohan PM, Ravichandran K, Jayaraj RSC, Rana TS (2020) Ensuring the adaptive potential of coastal wetlands of India-the need of the hour for sustainable management. Wetl Ecol Manag. https://doi.org/ 10.1007/s11273-020-09742-z

Ramsar Convention on Wetlands (2018) Global wetland outlook: state of the world's wetlands and their services to people 2018. Gland, Switzerland. Ramsar Convention Secretariat. https://www.ramsar.org/sites/default/files/ flipbooks/ramsar_gwo_english_web.pdf. Accessed 27 July 2021

Ravinesh R, Biju Kumar A, Anjana VL (2021) Diversity and distribution of molluscan fauna of Asthamudi estuary, Kerala, India. Wetl Ecol Manag. https://doi.org/10.1007/ s11273-021-09791-y

Reshmi RR, Deepa Nair K, Zachariah EJ, Vincent SGT (2015) Methanogenesis: seasonal changes in human impacted regions of Ashtamudi estuary (Kerala, South India). Estuar Coast Shelf Sci 156:144-154. https://doi.org/10.1016/j. ecss.2014.11.031

Sajinkumar KS, Bincy HS, Bouali EH, Oommen T, Vishnu CL, Anilkumar Y, Thrivikramji KP, Keerthy S (2020) Picturing beach erosion and deposition trends using PSInSAR: an example from the non-barred southern west coast of India. Wetl Ecol Manag. https://doi.org/10.1007/s11273-02009706-3

Salahudeen JH, Reshmi RR, Anoop Krishnan K, Ragi MS, Vincent SGT (2018) Denitrification rates in estuarine sediments of Ashtamudi, Kerala, India. Environ Monit Assess 190(6):323. https://doi.org/10.1007/s10661-0186698-z

Sarath NG, Puthur JT (2020) Heavy metal pollution assessment in a mangrove ecosystem scheduled as a community reserve. Wetl Ecol Manag. https://doi.org/10.1007/s11273020-09764-7 
Saxena MM (2021) Freshwater sponge fauna (Porifera) of coastal waters of India. Wetl Ecol Manag. https://doi.org/ 10.1007/s11273-020-09761-w

Schuyt K, Brander L (2004) The economic values of the world's wetlands. World Wildlife Fund, Zeist, The Netherlands

Srivastava J, Farooqui A, Thakur B, Seth P (2021) Palynomorph distribution in a mangrove ecosystem along environmental and salinity gradient: a tool for palaeoecological reconstruction. Wetl Ecol Manag. https://doi.org/10.1007/ s11273-021-09803-x

Sulochanan B, Lavanya S, Rohit P, Kripa V (2016) Hydrodynamics of coastal wetlands in Dakshina Kannada and their importance for avian fauna. Mar Fish Inf Serv 230:13-16
Vincent SGT, Reshmi RR, Hassan SJ, Nair KD, Varma A (2017) Predominant terminal electron accepting processes during organic matter degradation: spatio-temporal changes in Ashtamudi estuary, Kerala, India. Estuar Coast Shelf Sci 198:508-517. https://doi.org/10.1016/j.ecss.2017.05.013

Publisher's Note Springer Nature remains neutral with regard to jurisdictional claims in published maps and institutional affiliations. 